\title{
Water status in the Canary Islands related to energy requirements
}

\author{
Juan C. Santamarta ${ }^{\circledR} \cdot$ Ignacio Calvo Rubiales \\ Jesica Rodríguez-Martín (i) Noelia Cruz-Pérez ${ }^{\mathbb{B}}$
}

Received: 14 July 2020 / Accepted: 23 December 2021 / Published online: 8 February 2022

(C) The Author(s) 2022

\begin{abstract}
A review of the methods of obtaining water in the Canary Islands (Spain) is presented, dividing the islands into two groups: the eastern islands and the western islands. This division is due to the different origins of water resources, with western islands using mainly underground sources, while the eastern ones main source is seawater desalination. Water sources define the way in which water is obtained, as well as the energy expenditure to obtain it. In this review, the energy consumption of different methods of drinking water collection is studied, as well as the resources that make up the energy mix in the Canary Islands. In addition, a projection is made for drinking water consumption and energy consumption related to water use in the archipelago up till the year 2035, in order to observe the expected trends in these sectors.
\end{abstract}

Keywords Water demands - Projection - Renewable energy $\cdot$ Desalination $\cdot$ Water-energy nexus

J. C. Santamarta $(\bowtie) \cdot$ I. C. Rubiales · N. Cruz-Pérez Departamento de Ingeniería Agraria y del Medio Natural, Universidad de La Laguna (ULL), La Laguna (Tenerife), Spain

e-mail: jcsanta@ull.edu.es

J. Rodríguez-Martín

Departamento Técnicas Y Proyectos en Ingeniería Y Arquitectura, Universidad de La Laguna (ULL), Tenerife, Spain

\section{Introduction}

Oceanic islands have common patterns with respect to water resources with certain specific features, due among other reasons to (i) geological age, (ii) typology of the volcanic island, (iii) average altitude and orography, (iv) type of vegetation, (v) geographical location, (vi) volcanic constituent materials, and (vii) average rainfall (Santamarta et al., 2014). This common origin means that similar solutions may be found to problems shared by the islands, such as guaranteeing water supply, erosion control and soil conservation, as well as safety from major floods and landslides (Hughes \& Malmqvist, 2005).

Thirty years ago, hydrological planning in the Canary Islands was about increasing the water supply without considering the environmental or economic limitations, since this resource was necessary at any cost and was the basis of the islands' economic development. The environment was an irrelevant issue in the decision-making process in the field of hydrology. Currently, and with new regulations such as the Water Framework Directive, which is an EU Directive (Quevauviller, 2009), there is a tendency to conduct water management based on demand, giving priority to guaranteed and efficient water resources. Water planning on the islands is conducted through an Island Hydrological Plan, which is the basic instrument of hydrological planning, aimed at achieving the best possible way to meet all the islands' water demands. This is a document that includes all the specifications 
of the hydrological cycle of each island, an inventory of all the water facilities on the island; establishes the hydrological balance; and estimates the recharge of the aquifer. In short, it is the official document to know the hydrological status of each island, as well as to know the future trends of the island.

Regarding the water resources in the Canary Islands, there are two operating models: the western model (Tenerife, La Palma, La Gomera and El Hierro) and the eastern one (Gran Canaria, Fuerteventura and Lanzarote). In the western islands, water consumption is mainly supplied by groundwater in some cases; such as in Tenerife and La Palma, the percentages exceed $80 \%$ of total supply. Groundwater is complemented to a lesser extent by supply from desalination plants, especially on the island of Tenerife. As an exception, it should be noted that on the island of La Palma, there are no desalination plants providing water from the sea to supply the population. As for surface water resources, their quantity is not especially important in this group, and they only have some relevance in La Palma and La Gomera (Table 1).

In the eastern islands, the water supply comes mainly from seawater desalination plants (reverse osmosis). However there are certain exceptions; for instance, in the case of Gran Canaria, there are significant underground resources, extracted mainly from wells, as well as surface resources, stored by an extensive network of large dams (about 60) (Santamarta, 2014). These water resources are mainly used in agriculture. The urban supply, in Fuerteventura, is provided by seawater desalination plants. In Lanzarote, the supply is practically all from desalination with a percentage that exceeds $80 \%$. Lanzarote is an island where agricultural water consumption is substantial, though the urban and tourism water demand is greater.
There are island systems and areas which due to the low contribution of rainfall (Díaz, et al., 2011), between 100 and $250 \mathrm{~mm} /$ year, do not have the necessary aquifer recharge to satisfy water demand. In general, rainfall is irregular, from $100 \mathrm{~mm}$ in the south to $900 \mathrm{~mm}$ in the north of the islands (Gonzalo et al., 2017). Therefore, it is necessary to resort to industrial water production, by means of desalination plants. This implies an energy dependency for water production and high cost that some islands find difficult to meet. Regarding seawater desalination, according to the Canary Islands Government (CIATF, 2015), the number of desalination plants currently existing in the archipelago is 337 , with a total production capacity of drinking water (it should be noted that brine production has not been considered in these data), exceeding $660,000 \mathrm{~m}^{3} /$ day, and an annual production capacity estimated at 242 million $\mathrm{m}^{3} /$ year. Of the total production of desalinated water, approximately $70 \%\left(462,000 \mathrm{~m}^{3}\right)$ is used for drinking water supply, $29 \%(199,000$ $\left.\mathrm{m}^{3}\right)$ for irrigation and $1 \%\left(3,000 \mathrm{~m}^{3}\right)$ for industrial consumption. In the archipelago, the eastern islands (Gran Canaria, Fuerteventura and Lanzarote) allocate approximately between 13 and $18 \%$ of energy produced to desalination (González-Morales \& Ramón-Ojeda, 2019), whereas the energy impact is lower on the western islands: El Hierro consumes approximately $10 \%$ for this purpose (Frydrychowicz-Jastrzebska, 2018) and Tenerife 5\%, according to the Canary Islands Government (Plan Hidrológico de Tenerife, 2006). It should be noted that the reverse hydrowind plant (pumped-storage plant) on the island of El Hierro, La Gorona del Viento, has been operating since 2015, and it is possible that

Table 1 Assessment of water resources in the Canary Islands and future prospects

\begin{tabular}{|c|c|c|c|c|c|}
\hline Island & Surface water & $\begin{array}{l}\text { Groundwater } \\
\text { resources }\end{array}$ & $\begin{array}{l}\text { Desalination and } \\
\text { water reuse }\end{array}$ & Storage method & Future trends \\
\hline Hierro & Nil & High & Low & Water Gallery & Desalination \\
\hline La Palma & Scarce & High & Nil & Water Gallery & groundwater \\
\hline Gomera & Medium & High & Nil & Water Gallery & groundwater \\
\hline Tenerife & Scarce & High & Medium & Water Gallery & groundwater-Desalination \\
\hline Gran Canaria & High & Medium & Medium & Wells/Dams & $\begin{array}{l}\text { groundwater- Surface } \\
\text { water- Desalination }\end{array}$ \\
\hline Lanzarote & Nil & Scarce & High & Desalination & Desalination \\
\hline Fuerteventura & Scarce & Medium & High & Desalination/Wells & Desalination \\
\hline
\end{tabular}

Source: Santamarta, 2011 
this percentage has been modified. In fact, this project has enabled the island of El Hierro to become increasingly self-sufficient in terms of energy, and the model can be exported to similar areas due to the good performance it has shown on the island (Frydrychowicz-Jastrzebska, 2018).

We conclude this section by indicating that seawater desalination should be a complement to conventional systems for obtaining and producing water, and not the basis for an island's water supply, except in cases where there are no other options due to a lack of rainfall (i.e. less than $150 \mathrm{~mm} /$ year), as is the case of Fuerteventura or Lanzarote. Moreover, it should be noted that in the case of islands where it is necessary to produce water requiring energy, these energy sources should attempt to be sourced from renewable energies.

\section{Study area}

The Canary Islands (Spain) are composed of eight islands and five islets, covering an area of approximately $7,500 \mathrm{~km}^{2}$. They are located, on average, 1,400 kms from the nearest coasts of the European continent (the Iberian Peninsula) and $100 \mathrm{kms}$ off the western coast of the African continent (Western Sahara) (Fig. 1).

The main economic activity in the Canary Islands is the services sector with a weight of $75 \%$ of the total economy (de la Cruz et al., 2020). Tourism is the economic driving force of the Canary Islands since the archipelago is the third most popular tourist destination in Spain. Agriculture and fishing are also relevant
(1.7\% of GDP) (Minondo, 2010). Fruits and vegetables are important exports with crops being mainly vines, potatoes and bananas (García-Rodríguez et al., 2018). The limiting factor in the production of the latter is the availability of water (García-Rodríguez et al., 2016). Regarding industrial sector, this has little weight on the islands representing only about $7 \%$ of GDP (CEOE, 2019).

In the Canary Islands, availability of water resources and energy supply can be considered critical, since the population and the islands' economic development depend on these two factors. Water resources must be managed effectively, considering the unique characteristics of volcanic island systems. The main implication of being an archipelago is that the strategies and methodologies used in continental lands may not be valid for limited spaces, due to its vulnerability and dependence in the exterior (Lazrus, 2012).

Agriculture is the most water-demanding activity on the islands (this is valid for all the islands except for Lanzarote and Fuerteventura, where tourism and urban use have more weight). On the islands of La Palma, La Gomera, Tenerife and El Hierro, percentages for agricultural water demand exceed $80 \%$ of the total for this resource (Santamarta, 2013). Tourism also represents a significant water demand. In terms of hydrological planning on the Canary Islands, it is estimated that 300-850 L are consumed per tourist per day (Diaz Perez et al., 2018). Depending on the country, this estimation can range from 84 to $2000 \mathrm{~L}$ per tourist per day (Gössling et al., 2012), or be lower, as in the case of Morocco, which is between 300 and $600 \mathrm{~L}$ (Hadjikakou et al., 2013).
Fig. 1 Canary Islands belonging to the Kingdom of Spain, where Tenerife, La Palma, El Hierro and La Gomera are the western islands and Gran Canaria, Fuerteventura and Lanzarote are the eastern islands. Source: Google Earth

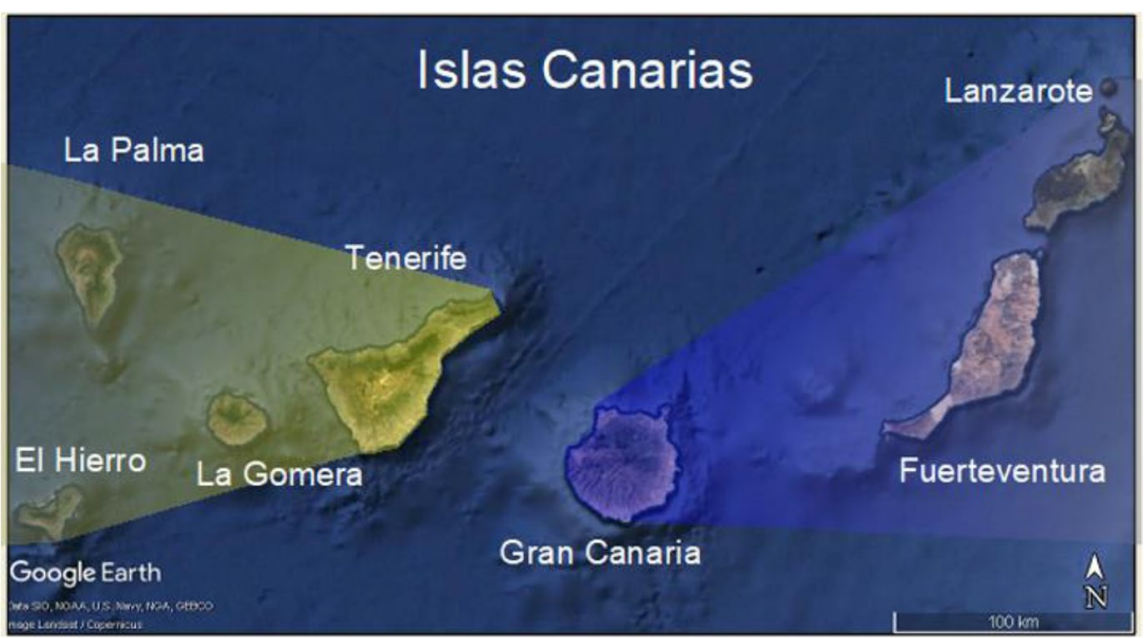


The following sections will therefore study the methods of obtaining drinking water in the Canary Islands and their relationship with the energy they demand. In addition, predictions have been made of what energy consumption on the islands is expected to be like in the coming years and how this may change our water model.

\section{Desalination vs reuse}

In the $1970 \mathrm{~s}$, desalinating $1 \mathrm{~m}^{3}$ of water required energy consumption of $22 \mathrm{kWh}$ (Latorre Carrión, 2004). Nevertheless, the application of new techniques has nowadays managed to reduce energy consumption to $2 \mathrm{kWh} /$ $\mathrm{m}^{3}$ (Naredo, 2007), and reaching values of $1.06 \mathrm{kWh} / \mathrm{m}^{3}$ at the present time (Gómez-Gotor et al., 2018). Despite this, some authors consider that instead of using desalination as solution to a lack of water (Aguilera-Klink et al., 2000), it would be less costly, in ecological terms, to undertake better management of water demand since "it is cheaper to save $1 \mathrm{~m}^{3}$ than to produce it". In fact, Naredo (2003) recognizes that "it is not very promising to support the future of water supply from the desalination of seawater reliant on oil" since it is known that the days of cheap oil reserves are counted. In the Canary Islands, $87 \%$ of energy used for desalination comes from oil, followed by residual steam (13\%) and wind power (0.02\%) (Romero-Ternero et al., 2005). Despite the fact that renewable energy covered $17.6 \%$ of the electricity demand in the Canary Islands in 2020 (data from the Government of the Canary Islands), there are still few desalination plants that operate self-sufficiently with renewable energies, less than $1 \%$ of the total installed in the Canary Islands (Padrón et al., 2019). In addition to energy consumption, the discharge of brine resulting from desalination is another serious drawback of this water production system (Kress et al., 2020). Studies have been carried out to analyse the tolerance of plants and marine animals to this excess salt, demonstrating its negative effects (Gacía \& Ballesteros, 2001). However, it has been found that after $25 \mathrm{~m}$ away from the coast, the dilution of the brine is practically total.

Furthermore, the process of wastewater treatment and subsequent reuse (defined by Azqueta and Ferreiro (1994) as a "structural system of hydrological planning" may represent a significant decrease in the water supply.

\section{Introduction to energy production systems in the Canary Islands}

As a target for 2050, the European Union has set itself the goal of achieving an 80-95\% reduction in greenhouse gas emissions (Connolly et al., 2016), adding a further target that renewable energies should cover $20 \%$ of total energy consumption by 2020. In Spain, the percentage covered by renewable energies within the country's energy mix is 33\% (Ruiz-Romero et al., 2013), which means that Spain still shows a great dependence on oil. Energy in the Canary Islands is mostly produced by thermoelectric power plants (Schallenberg-Rodríguez et al., 2014) (Fig. 2). The archipelago produces all the electrical energy it consumes (Table 2), and the most demanding sectors are those areas with high tourist concentrations and water desalination plants, whose consumption can be estimated at about $30 \%$ of all electricity consumption on the islands (Sadhwani and Veza, 2008).

The first energy resource that supplied electricity in the Canary Islands was hydroelectric power. Between the
Fig. 2 Installed power in the Canary Islands (MW), year 2013. Source: prepared by authors

\section{Amount of installed power in MW by energy source}

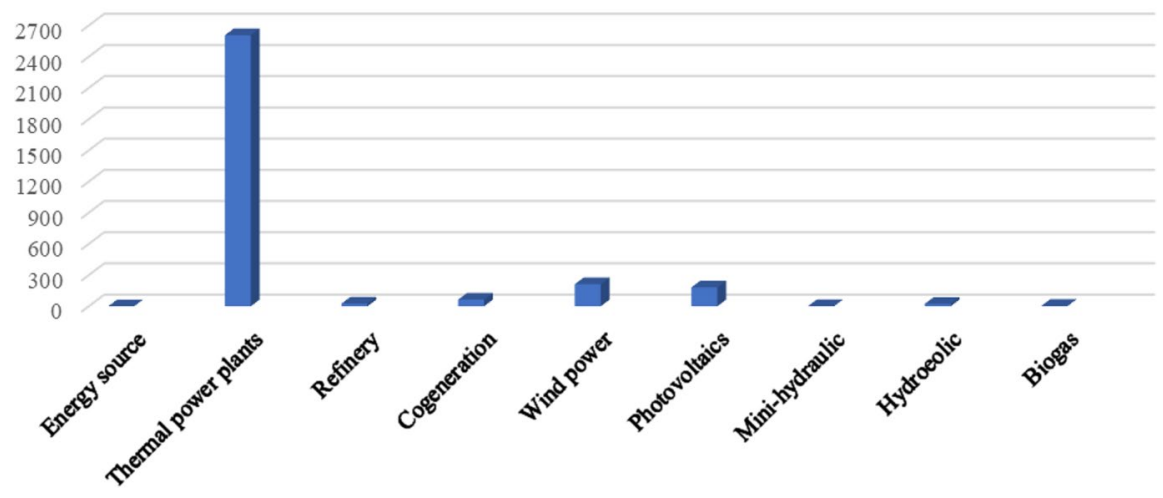


Table 2 Produced energy in the Archipelago (2010/2018 period). Source: prepared by authors

\begin{tabular}{llllllll}
\hline \multicolumn{7}{l}{ Produced energy in the Canary Islands (MWh) } \\
\hline Year & Tenerife & La Gomera & La Palma & El Hierro & Gan Canaria & Fuerteventura & Lanzarote \\
\hline 2000 & 2120,5 & 44,2 & 186,7 & 21,8 & 2470,8 & 346,6 & 525,3 \\
2001 & 2289 & 44,6 & 182,7 & 9,3 & 2646,8 & 395,3 & 573,7 \\
2002 & 2448,2 & 49,9 & 181,7 & 25,6 & 2710,6 & 415,3 & 609,5 \\
2003 & 2668,6 & 55,6 & 203,8 & 27,6 & 2950,7 & 460,3 & 669,4 \\
2004 & 2889,1 & 57,6 & 219,6 & 30,6 & 3134,9 & 504 & 720 \\
2005 & 3034 & 58,3 & 21,818 & 32,2 & 3272,4 & 554,8 & 755,3 \\
2006 & 3185,9 & 60,5 & 228,4 & 34,4 & 3369,7 & 610 & 789,4 \\
2007 & 3327,6 & 60,9 & 238,7 & 36,1 & 3437,5 & 620,6 & 807,8 \\
2008 & 3402 & 64 & 241,6 & 38 & 3495,9 & 629,9 & 821,1 \\
2009 & 3277 & 62,5 & 242,2 & 38 & 3434,4 & 583 & 786,2 \\
2010 & 3235,2 & 61,1 & 230,8 & 35,8 & 3308,2 & 584,3 & 776,6 \\
2011 & 3194,8 & 65,2 & 236,5 & 38,6 & 3306 & 602,5 & 788,5 \\
2012 & 3241,7 & 65,5 & 240,8 & 40,6 & 3287,1 & 600,4 & 789,1 \\
2013 & 3116,6 & 62,7 & 225,7 & 42,2 & 3186,6 & 581,1 & 776,7 \\
2014 & 3065,6 & 61,5 & 225,9 & 40 & 3156,6 & 592 & 788,9 \\
2015 & 3109,5 & 63,5 & 236 & 40,4 & 3176 & 604,3 & 799,4 \\
2016 & 3171,4 & 65,5 & 237,5 & 42 & 3212,6 & 630,8 & 802,2 \\
2017 & 3252,4 & 69 & 234,8 & 41,5 & 3246,2 & 656 & 817,5 \\
2018 & 3251,6 & 67,7 & 243,7 & 37,7 & 3216 & 647,9 & 816,5 \\
\hline
\end{tabular}

(c) High dependence on fossil fuels.

(d) Pressure for the integration of renewable energies into the electricity system, since in 2019 only $16 \%$ of the electricity mix of the Canary Islands was covered by renewable energies (Gobierno de Canarias, 2019). (e) Administrative and environmental difficulties for the development of new electricity lines and energy projects.

(f) Controversy in the location of new power stations.

(g) Complexity and high bureaucracy for the authorisation of new power generation equipment.

(h) No interconnection between the islands' electricity systems and high construction and operating costs.

(i) Low efficiency in potable water supply services (in some municipalities about $50 \%$ of the potable water in the network is lost, with the consequent waste of energy in producing water that is never used) (Custodio et al., 2016).

\section{Water-energy nexus in the Canary Islands}

Water can be considered an energy resource when it is stored and turbined, even when small hydroelectric exploitation equipment is installed (mini-hydraulic of 
less than $10 \mathrm{MW}$ ). In other cases, where water is the resource we aim to obtain, it can be achieved by gravity, such as the case of a water gallery, which is a horizontal water mine that perforates the interior of the ground to reach the aquifer and drain the water (Santamartal, 2016).

Another important part of the energy consumption in an integral water cycle is the water treatment process. In a wastewater treatment plant (WWTP), the equipment requires significant energy consumption. Sewage water from WWTPs in urban centres located at high altitudes could also be an energy resource that has not yet been exploited in the Canary Islands, as a potential to install mini hydros in a sewer line falling to a WWTP. Finally, with regard to seawater desalination, although energy consumption has been significantly reduced, it continues to be high and very disparate depending on the type of facility, with economies of scale also having an influence on larger facilities and on costs. In this matter, the new energy recovery techniques in reverse osmosis plants, with specific consumptions in the range of 2.0 to 3.0 $\mathrm{kWh} / \mathrm{m}^{3}$, also stand out (Romero-Ternero et al., 2005).

\section{Projection of hydrological and energy planning in the western islands in the archipelago for the period 2016-2035}

Water supply in the future will continue to be devoted to the same sectors, and for the projection period, we are considering the same allocations by use with which consumption has been estimated in the years preceding 2014. It will be assumed, for this first projection, that in the next 15 years, there will be no great variations in water consumption ratios, due to the fact that no significant changes are expected in the population of the Canary Islands, the areas devoted to the primary sector and the number of incoming tourists to the islands.

In the western islands, the forecast for general water expenditure is downwards, mainly due to a decreasing estimation of hectares used for crop cultivation and a decrease in the average allocation per inhabitant resulting from the regional average as a representative consumption of each individual. In this way, consumption is dominated by agriculture and domestic expenditure, as has been the case in the past.

The energy consumption for the projected period will depend not only on the evolution of the population, the number of tourists or the number of workers in the industrial sector, but also on their energy use.
Normally, the larger the population, the more services, more public consumption, more likelihood of industries with high consumption, etc., exist. However, we have attempted to develop a forecast that is not only adjusted to the overall evolution of the population. For this reason, we have calculated the consumption ratios according to three groups. These groups are the permanent population, the tourism population (permanent population plus tourism) and industrial workers (Table 3).

Depending on the population segment, their influence will be different on the type of consumption in a more direct and significant way.

A significant part of all hydrocarbons will be consumed as primary energy for electricity generation (Table 4). If the electricity generation mix does not change significantly, this electricity production will

Table 3 Projection of water consumption on the Western Canary Islands

\begin{tabular}{llllll}
\hline Tenerife (hm ${ }^{3} /$ year) & $\mathbf{2 0 1 5}$ & $\mathbf{2 0 2 0}$ & $\mathbf{2 0 2 5}$ & $\mathbf{2 0 3 0}$ & $\mathbf{2 0 3 5}$ \\
Domestic & 72,9 & 72,4 & 65,2 & 65,3 & 65,1 \\
Agricultural & 83 & 85 & 82,9 & 79,7 & 79,5 \\
Touristic & 22 & 22,3 & 21,7 & 20,7 & 21 \\
Industrial & 3,4 & 3,5 & 3,4 & 3,5 & 3,7 \\
Urban & 8,4 & 8,3 & 8,5 & 8,5 & 8,5 \\
Total & 189,8 & 191,5 & 181,7 & 177,8 & 177,8 \\
La Gomera (hm ${ }^{3} /$ year) & $\mathbf{2 0 1 5}$ & $\mathbf{2 0 2 0}$ & $\mathbf{2 0 2 5}$ & $\mathbf{2 0 3 0}$ & $\mathbf{2 0 3 5}$ \\
Domestic & 1,48 & 1,43 & 1,45 & 1,48 & 1,49 \\
Agricultural & 4,28 & 4,17 & 4,16 & 4,19 & 4,19 \\
Touristic & 0,78 & 0,85 & 0,93 & 0,79 & 0,8 \\
Industrial & 0,026 & 0,027 & 0,025 & 0,025 & 0,025 \\
Urban & 0,2 & 0,19 & 0,19 & 0,2 & 0,2 \\
Total & 6,76 & 6,67 & 6,76 & 6,68 & 6,7 \\
El Hierro (hm ${ }^{3} /$ year) & $\mathbf{2 0 1 5}$ & $\mathbf{2 0 2 0}$ & $\mathbf{2 0 2 5}$ & $\mathbf{2 0 3 0}$ & $\mathbf{2 0 3 5}$ \\
Domestic & 0,75 & 0,68 & 0,64 & 0,65 & 0,67 \\
Agricultural & 2,02 & 2,03 & 1,88 & 1,82 & 1,75 \\
Touristic & 0,02 & 0,02 & 0,01 & 0,02 & 0,02 \\
Industrial & 0,014 & 0,014 & 0,014 & 0,013 & 0,013 \\
Urban & 0,1 & 0,09 & 0,08 & 0,09 & 0,09 \\
Total & 2,9 & 2,82 & 2,63 & 2,58 & 2,54 \\
La Palma (hm ${ }^{3} /$ year) & $\mathbf{2 0 1 5}$ & $\mathbf{2 0 2 0}$ & $\mathbf{2 0 2 5}$ & $\mathbf{2 0 3 0}$ & $\mathbf{2 0 3 5}$ \\
Domestic & 6,88 & 6,44 & 6,36 & 6,04 & 5,95 \\
Agricultural & 63,98 & 62,12 & 59,75 & 57,76 & 58,22 \\
Touristic & 0,47 & 0,5 & 0,53 & 0,5 & 0,51 \\
Industrial & 0,188 & 0,189 & 0,19 & 0,187 & 0,183 \\
Urban & 0,78 & 0,75 & 0,75 & 0,74 & 0,73 \\
Total & 72,29 & 70 & 67.56 & 65.23 & 65.59 \\
\hline & & & & & \\
\hline & & &
\end{tabular}




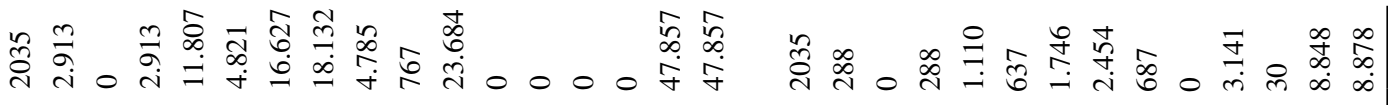

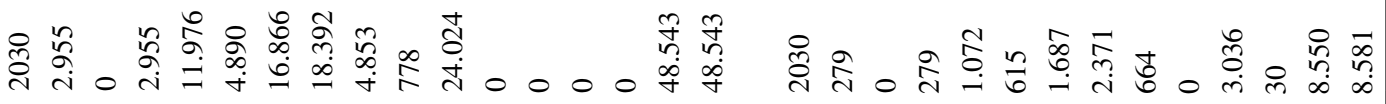

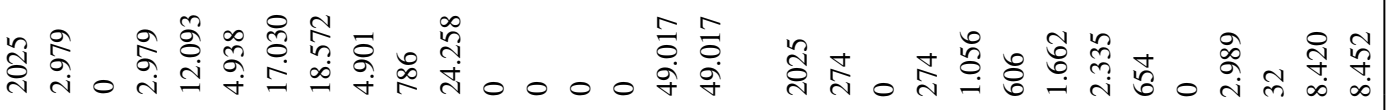

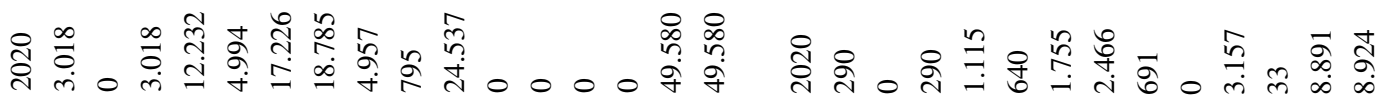

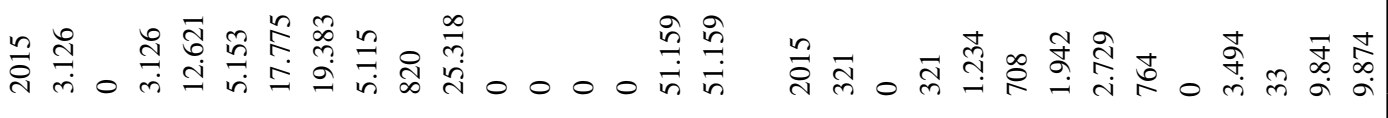

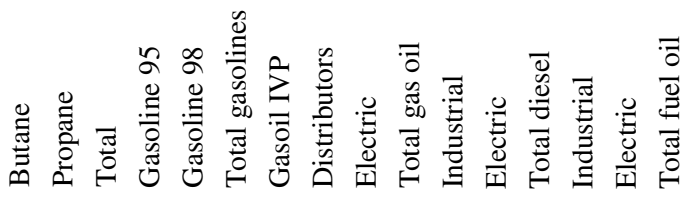

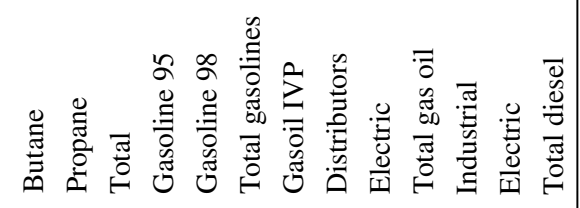

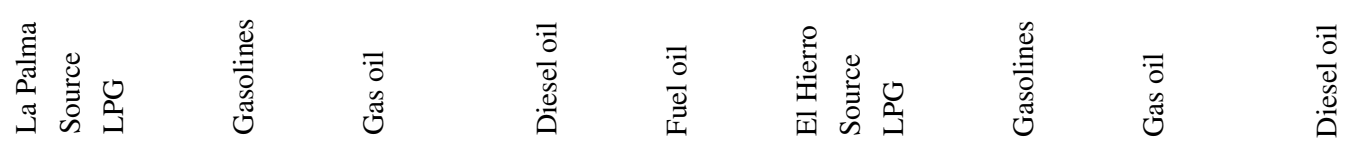

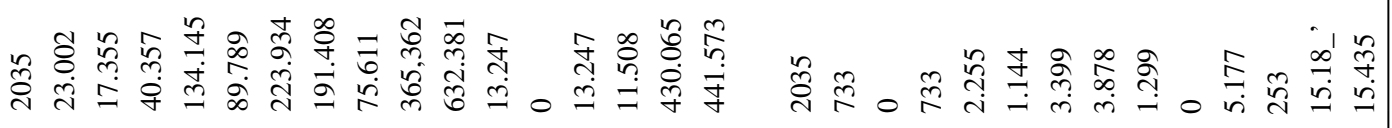

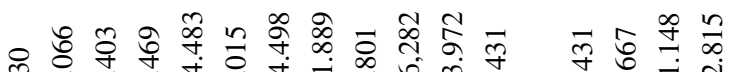

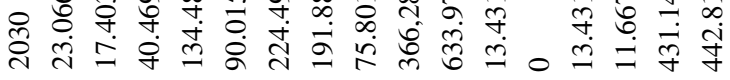

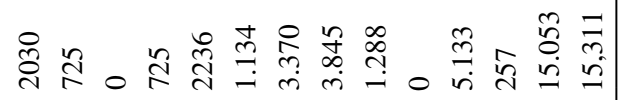

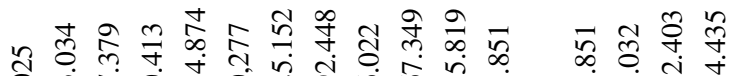

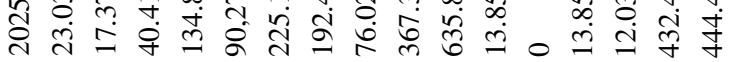

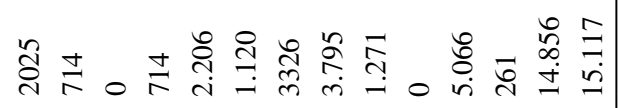

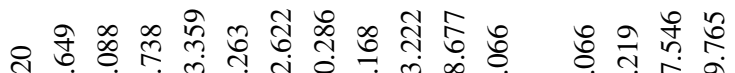
至

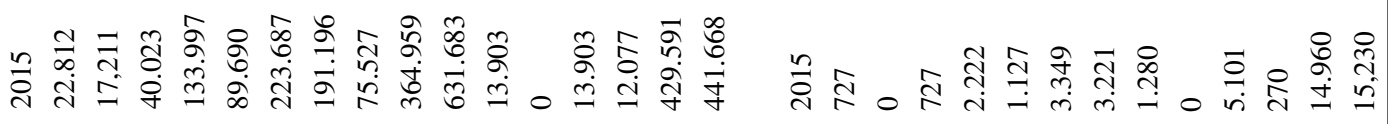

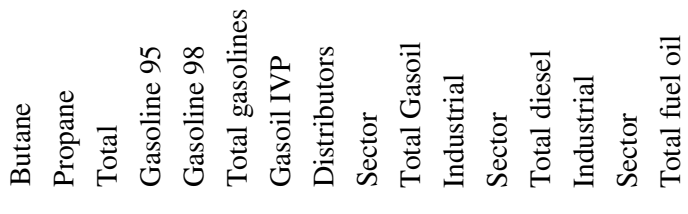

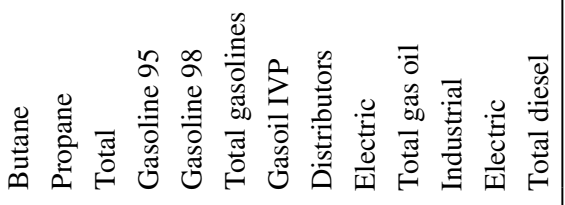

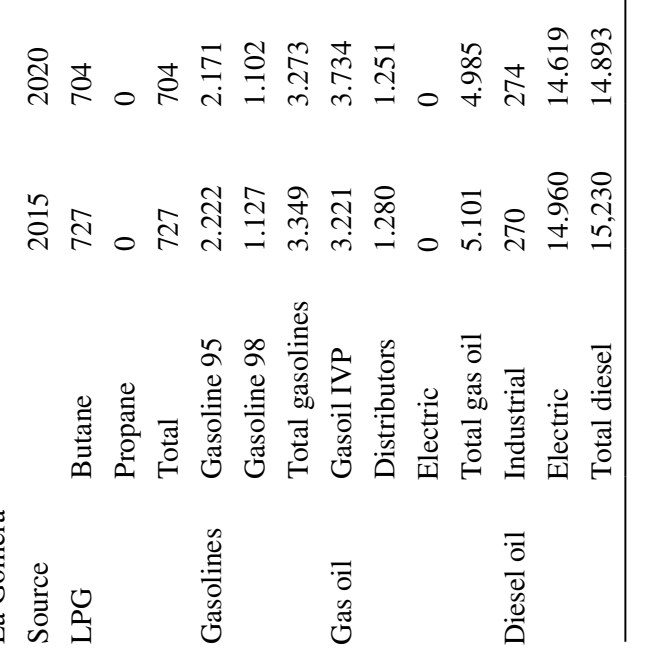




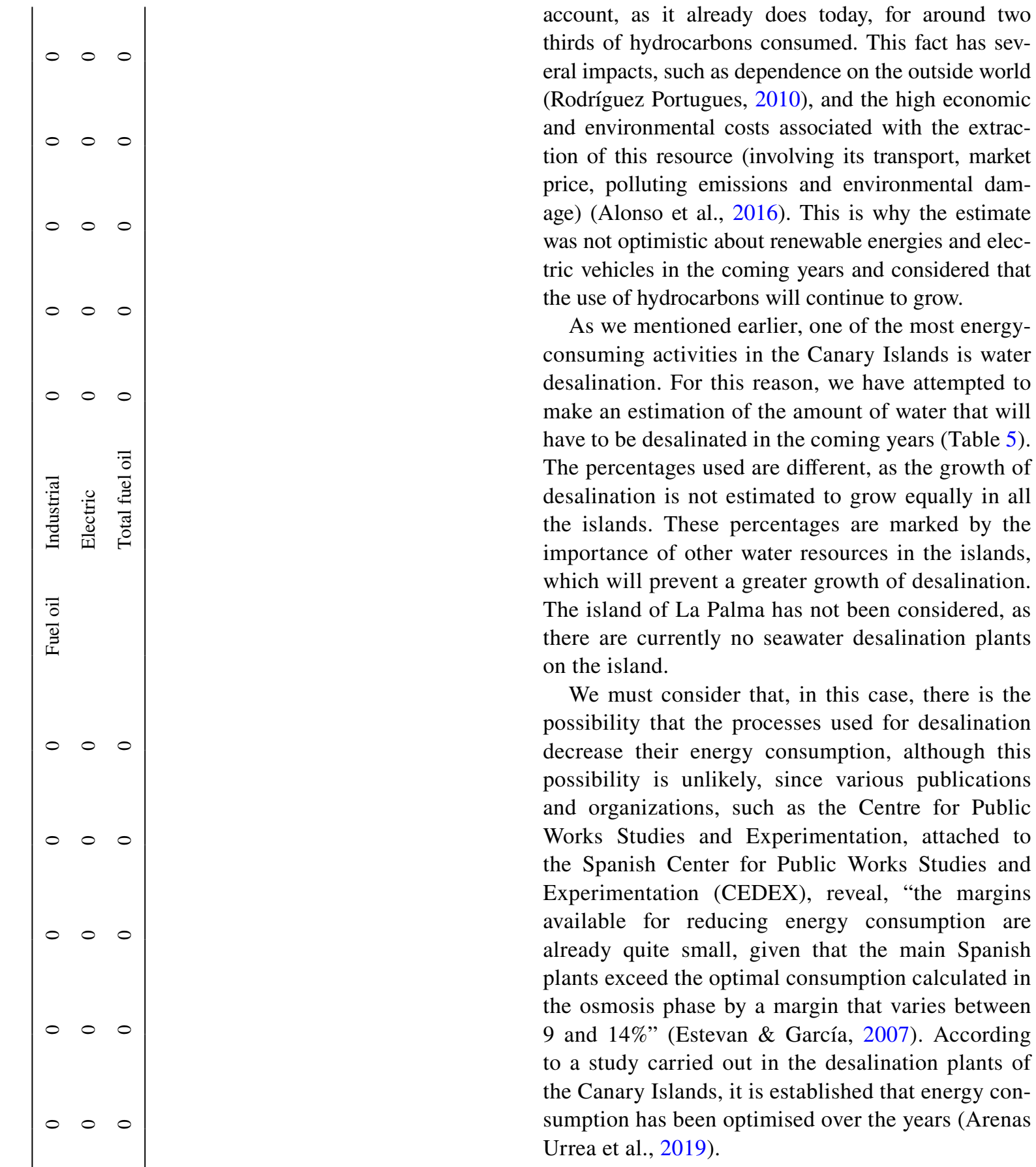

account, as it already does today, for around two thirds of hydrocarbons consumed. This fact has several impacts, such as dependence on the outside world (Rodríguez Portugues, 2010), and the high economic and environmental costs associated with the extraction of this resource (involving its transport, market price, polluting emissions and environmental damage) (Alonso et al., 2016). This is why the estimate was not optimistic about renewable energies and electric vehicles in the coming years and considered that As of hydrocarbons will continue to grow.

As we mentioned earlier, one of the most energyconsuming activities in the Canary Islands is water desalination. For this reason, we have attempted to make an estimation of the amount of water that will have to be desalinated in the coming years (Table 5). The percentages used are different, as the growth of desalination is not estimated to grow equally in all the islands. These percentages are marked by the importance of other water resources in the islands, which will prevent a greater growh of desalination. there are currently no seawater desalination plants on the island.

We must consider that, in this case, there is the possibility that the processes used for desalination perease their energy consumption, although this and organizations, such as the Centre for Public Works Studies and Experimentation, attached to the Spanish Center for Public Works Studies and Experimentation (CEDEX), reveal, "the margins available for reducing energy consumption are plants exceed the optimal consumption calculated in the osmosis phase by a margin that varies between 9 and 14\%" (Estevan \& García, 2007). According to a study carried out in the desalination plants of sumption has been optimised over the years (Arenas Urrea et al., 2019).

\section{Future prospects in the Canary Islands}

The Canary Islands are increasingly opting for a future with renewable energies (Gils \& Simon, 2017), in fact, this is the objective of the draft law 
Table 5 Assumptions on energy consumption and waste generated in desalination in 2025

\begin{tabular}{|c|c|c|c|c|c|c|c|}
\hline \multirow{2}{*}{$\begin{array}{l}\text { Desalinated water } \\
\text { Tenerife (2025) }\end{array}$} & \multirow{2}{*}{$\frac{\text { Volume }}{\mathrm{hm}^{3}}$} & \multicolumn{2}{|c|}{ Energy consumption } & \multicolumn{3}{|c|}{ Tons of hydrocarbons (Tm) } & \multirow{2}{*}{$\frac{\text { Brine waste }}{\mathrm{hm}^{3}}$} \\
\hline & & GWh & Ton oil equivalent & Gas oil & Diesel & Fuel oil & \\
\hline $25 \%$ of supply & 45,40 & 227,00 & $19.525,00$ & $19.134,00$ & $22.724,00$ & $26.214,00$ & 55,50 \\
\hline $50 \%$ of supply & 90,30 & 454,00 & $39.050,00$ & $33.267,00$ & $45.443,00$ & $52,428,00$ & 111,00 \\
\hline $75 \%$ of supply & 136,20 & 631,00 & $53.576,00$ & $57.401,00$ & $63.172,00$ & $73.642,00$ & 166,50 \\
\hline La Gomera (2025) & $\mathrm{hm}^{3}$ & GWh & Ton oil equivalent & Gas oil & Diesel & Fuel oil & $\mathrm{hm}^{3}$ \\
\hline $20 \%$ of supply & 1,35 & 6,30 & 532,00 & 570,00 & 677,00 & 731,00 & 1,70 \\
\hline $35 \%$ of supply & 2,37 & 11,30 & $1.018,00$ & 997,00 & $1.134,00$ & $1.366,00$ & 2,90 \\
\hline $50 \%$ of supply & 3,33 & 16,90 & $1.454,00$ & $1.425,00$ & $1.692,00$ & $1.952,00$ & 4,10 \\
\hline El Hierro (2025) & $\mathrm{hm}^{3}$ & GWh & Ton oil equivalent & Gas oil & Diesel & Fuel oil & $\mathrm{hm}^{3}$ \\
\hline $50 \%$ of supply & 1,31 & 6,60 & 565,00 & 553,00 & 657,00 & 753,00 & 1,61 \\
\hline $75 \%$ of supply & 1,97 & 9,90 & 347,00 & 330,00 & 936,00 & $1.137,00$ & 2,40 \\
\hline $95 \%$ of supply & 2,50 & 12,50 & $1.073,00$ & $1.051,00$ & $1.249,00$ & $1.440,00$ & 3,00 \\
\hline
\end{tabular}

entitled "Law on Climate Change and Energy Transition of the Canary Islands". There are more and more studies focused on studying the carbon footprint in the archipelago of various sectors: tourism (Diaz Perez et al., 2018; Pérez et al., 2019), transport (Antequera et al., 2021) and desalination (Leon et al., 2021), in order to know the starting point from which to approach the reduction of emissions in the archipelago.

Renewable energy related fields such as geothermal (Perlock et al., 2008), wave and offshore wind (Veigas \& Iglesias, 2013) and solar are being explored. The objective is to decarbonize the archipelago, use renewable energies and reduce the dependence on fossil fuels so closely linked today to the production of drinking water in the Canary Islands.

\section{Conclusions}

In the Canary Island archipelago, energy and water are totally linked, given that on some islands, the only possibility to cover water demand is through using desalination plants, which, in turn, rely on energy. As tourism and the local population are showing upward trends on the islands, with the islands establishing themselves as a popular tourist destination and a fixed place of residence for many people, it is necessary to establish energy planning that considers renewable energies in order to meet demand. Similarly, water planning that considers water reuse is required. Indeed, it is increasingly necessary to close the water cycle (from supply to reuse) due to decreasing rainfall that directly affects aquifer recharge, which has traditionally been the source of water for the Canary Islands (statements made on the basis of hydrological studies conducted by the Government of the Canary Islands in their Hydrological Plans for each island). From now on, it will be necessary to implement measures to reuse water, either to recharge aquifers artificially or to use this water for purposes that are currently covered by drinking water.

The water and energy nexus in the Canary Islands is key, as anything that affects energy costs will directly affect water supply on the islands, in particular the industrial production of water. According to the results of the projections, the main need, in terms of water consumption, is not to implement policies aimed at increasing water production or production from non-conventional resources, rather the most logical priority is to promote policies to enhance saving and rational consumption.

Wastewater reuse in tourist facilities, for example, should be encouraged as an alternative for irrigation of green areas and for use in closed circuits (cooling of equipment, etc.). In addition, drinking water distribution networks should be improved to avoid losses of drinking water on the way to the end user. Finally, a more rational use of water by agriculture would be necessary to avoid flood irrigation, which requires much larger quantities of water than drip irrigation. 
Acknowledgements This project has been developed in the framework of the Arsinoe project "Climate resilient regions through systemic solutions and innovations H2020-LC-GD-2020-2".

Funding Open Access funding provided thanks to the CRUE-CSIC agreement with Springer Nature.

\section{Declarations}

Conflict of interests The authors declare no competing interests.

Open Access This article is licensed under a Creative Commons Attribution 4.0 International License, which permits use, sharing, adaptation, distribution and reproduction in any medium or format, as long as you give appropriate credit to the original author(s) and the source, provide a link to the Creative Commons licence, and indicate if changes were made. The images or other third party material in this article are included in the article's Creative Commons licence, unless indicated otherwise in a credit line to the material. If material is not included in the article's Creative Commons licence and your intended use is not permitted by statutory regulation or exceeds the permitted use, you will need to obtain permission directly from the copyright holder. To view a copy of this licence, visit http://creativecommons.org/licenses/by/4.0/.

\section{References}

Aguilera-Klink, Federico, Pérez-Moriana, Eduardo, \& Sánchez-García, J. (2000). The social construction of scarcity. The case of water in Tenerife (Canary Islands). Ecological E, 34(2), 233-245. https://doi.org/10.1016/ S0921-8009(00)00160-9

Alonso, P. M., Hewitt, R., Pacheco, J. D., Bermejo, L. R., Jiménez, V. H., Guillén, J. V., Bressers, H., \& de Boer, C. (2016). Losing the roadmap: Renewable energy paralysis in Spain and its implications for the EU low carbon economy. Renewable Energy, 89(2016), 680-694. https://doi. org/10.1016/j.renene.2015.12.004

Antequera, P. D., Jaime, D., \& Abel, L. (2021). Tourism, transport and climate change: The carbon footprint of international air traffic on islands. Sustainability, 13(4), 1795. https://doi.org/10.3390/su13041795

Azqueta Oyarzun, Diego; Ferreiro, A. (1994). Análisis económico y gestión de recursos naturales (D. L. Alianza (ed.)).

CEOE. (2019). La Economía Canaria en Gráficos (p. 132). https://ceoe-tenerife.com/wp-content/uploads/2019/04/ 2018-la-economia-canaria-en-graficos.pdf

CIATF. (2015). Anejo 2. Documento elaborado por la Dirección General de Aguas del Gobierno de Canarias en Desarrollo del Artículo 9 de la DMA: "Análisis económico y recuperación de costes" (p. 327).

Connolly, D., Lund, H., \& Mathiesen, B. V. (2016). Smart Energy Europe: The technical and economic impact of one potential $100 \%$ renewable energy scenario for the
European Union. Renewable and Sustainable Energy Reviews, 60, 1634-1653. https://doi.org/10.1016/j.rser. 2016.02.025

Custodio, E., Cabrera, M. del C., Poncela, R., Puga, L. O., Skupien, E., \& del Villar, A. (2016). Groundwater intensive exploitation and mining in Gran Canaria and Tenerife, Canary Islands, Spain: Hydrogeological, environmental, economic and social aspects. Science of the Total Environment, 557-558, 425-437. https://doi.org/10. 1016/j.scitotenv.2016.03.038

de la Cruz del Río-Rama, M., Maldonado-Erazo, C. P., Álvarez-García, J., \& Durán-Sánchez, A. (2020). Cultural and natural resources in tourism Island: Bibliometric mapping. Sustainability (Switzerland), 12(2). https://doi.org/ 10.3390/su12020724

Díaz, F. J., Tejedor, M., Jiménez, C., \& Dahlgren, R. A. (2011). Soil fertility dynamics in runoff-capture agriculture, Canary Islands, Spain. Agriculture, Ecosystems and Environment, 144, 253-261. https://doi.org/10.1016/j.agee. 2011.08.021

Diaz Perez, F. J., Pino Otin, M. R., Mouhaffel, A. G., Martin, R. D., \& Chinarro, D. (2018). Energy and water consumption and carbon footprint in tourist pools supplied by desalination plants: Case study, the canary islands. IEEE Access, 6, 11727-11737. https://doi.org/10.1109/ ACCESS.2018.2808923

Estevan, A., \& García, M. (2007). El consumo de energía en la desalación de agua de mar por ósmosis inversa : Situación actual y perspectivas. Ingeniería Civil, 148, 113-121.

Frydrychowicz-Jastrzebska, G. (2018). El Hierro renewable energy hybrid system: A tough compromise. Energies, 21. https://doi.org/10.3390/en11102812

Gacía, E., \& Ballesteros, E. (2001). El impacto de las plantas desalinizadoras sobre el medio marino: la salmuera en las comunidades bentónicas mediterráneas. ... Internacional: El Plan Hidrológico Nacional y La ..., Mabrook 1994, 1-13. http://www2.uah.es/tiscar/Complem_EIA/impactodesaladoras.pdf

García-Rodríguez, J. L., García-Rodríguez, F. J., \& CastillaGutiérrez, C. (2016). Human heritage and sustainable development on arid islands: The case of the Eastern Canary Islands. Island Studies Journal, 11(1), 113-130.

García-Rodríguez, J. L., Castilla-Gutiérrez, C., \& GarcíaRodríguez, F. J. (2018). Internal borders and external factors in outermost island regions. The case of the Canary Islands. European Planning Studies, 26(5), 1028-1040. https://doi.org/10.1080/09654313.2018. 1428532

Gils, H. C., \& Simon, S. (2017). Carbon neutral archipelago $-100 \%$ renewable energy supply for the Canary Islands. Applied Energy, 188, 342-355. https://doi.org/10. 1016/j.apenergy.2016.12.023

Gobierno de Canarias. (2019). Anuario Energético de Canarias 2019 (p. 340). Consejería de Transición Ecológica, Lucha contra el Cambio Climático y Planificación Territorial. https://www.energiagrancanaria.com/ wp-content/uploads/2020/10/anuarioelectricocanarias2 019-pub.pdf

Gómez-Gotor, A., Del Río-Gamero, B., Prieto Pardo, I., \& Casañas, A. (2018). The history of desalination in the 
Canary Islands. Desalination, 428, 86-107. https://doi. org/10.1016/j.desal.2017.10.051

González-Morales, A., \& Ramón-Ojeda, A. Á. (2019). La desalación de agua de mar en las Canarias Orientales: los casos de Lanzarote y Fuerteventura. Agua y Territorio, 13, 15-26. https://doi.org/10.17561/at.13.3722

Gonzalo, E., Philippe, Q., \& Enrique, S. M. E. V. (2017). Climate change policy and water resources in the EU and Spain. A closer look into the Water Framework Directive. Environmental Science and Policy, 69, 1-12. https://doi. org/10.1016/j.envsci.2016.12.006

Gössling, S., Peeters, P., Hall, C. M., Ceron, J. P., Dubois, G., Lehmann, L. V., \& Scott, D. (2012). Tourism and water use: Supply, demand, and security. An international review. Tourism Management, 33(1), 1-15. https://doi.org/ 10.1016/j.tourman.2011.03.015

Hadjikakou, M., Chenoweth, J., \& Miller, G. (2013). Estimating the direct and indirect water use of tourism in the eastern Mediterranean. Journal of Environmental Management, 114, 548-556. https://doi.org/10.1016/j.jenvman. 2012.11.002

Hughes, S. J., \& Malmqvist, B. (2005). Atlantic Island freshwater ecosystems: Challenges and considerations following the EU Water Framework Directive. Hydrobiologia, 544(1), 289-297. https://doi.org/10.1007/ s10750-005-1695-y

Kress, N., Gertner, Y., \& Shoham-frider, E. (2020). Seawater quality at the brine discharge site from two mega size seawater reverse osmosis desalination plants in Israel ( Eastern Mediterranean ). Water Research, 171, 115402. https://doi.org/10.1016/j.watres.2019.115402

Latorre Carrión, M. (2004). Costes económicos y medioambientales de la desalación de agua de mar (pp. 495-507). IV Congreso Ibérico de Gestión y Planificación del Agua.

Lazrus, H. (2012). Sea change: Island communities and climate change. Annual Review of Anthropology, 41, 285-301. https://doi.org/10.1146/annurev-anthro-092611-145730

Leon, F., Ramos, A., Vaswani, J., Mendieta, C., \& Brito, S. (2021). Climate Change Mitigation Strategy through Membranes Replacement and Determination Methodology of Carbon Footprint in Reverse Osmosis RO Desalination Plants for Islands and Isolated Territories. Water, 13(3), 293. https://doi.org/10.3390/w13030293

Minondo, A. (2010). Exports' productivity and growth across Spanish regions. Regional Studies, 44(5), 569-577. https://doi.org/10.1080/00343400902783255

Naredo, J. M. (2003). La encrucijada de la gestión del agua en España. Archipiélago: Cuadernos de Crítica de La Cultura, 57, 17-33.

Naredo, J. M. (2007). Costes y cuentas del agua: Propuestas desdeel enfoque ecointegrador ( $\mathrm{pp}$. 1-53). Costes y Cuentas del agua en Cataluña en relación con la Directiva Marco del Agua.

Padrón, I., Avila, D., Marichal, G. N., \& Rodríguez, J. A. (2019). Assessment of Hybrid Renewable Energy Systems to supplied energy to Autonomous Desalination Systems in two islands of the Canary Archipelago. Renewable and Sustainable Energy Reviews, 101(February 2018), 221230. https://doi.org/10.1016/j.rser.2018.11.009
Pérez, F. J. D., Martín, R. D., Trujillo, F. J. P., Díaz, M., \& Mouhaffel, A. G. (2019). Consumption and emissions analysis in domestic hot water hotels. Case study: Canary Islands. Sustainability (Switzerland), 11(3), 1-17. https:// doi.org/10.3390/su11030599

Perlock, P. A., González, P. J., Tiampo, K. F., RodríguezVelasco, G., Samsonov, S., \& Fernández, J. (2008). Time evolution of deformation using time series of differential interferograms: Application to La Palma Island (Canary Islands). Pure and Applied Geophysics, 165(8), 15311554. https://doi.org/10.1007/s00024-004-0388-7

Piña-Varas, P., Ledo, J., Queralt, P., Marcuello, A., Bellmunt, F., Hidalgo, R., \& Messeiller, M. (2014). 3-D Magnetotelluric Exploration of Tenerife Geothermal System (Canary Islands, Spain). Surveys in Geophysics, 35(4), 1045-1064. https://doi.org/10.1007/s10712-014-9280-4

Plan Hidrológico de Tenerife. (2006). Anejo 3. Documento elaborado por la Dirección General de Aguas del Gobierno de Canarias en desarollo del artículo 8 de la DMA (p. 240).

Quevauviller, P. (2009). News from the Water Front * Water Framework Directive. Environment, 7(2), 111-116.

Rodríguez Portugues, M. (2010). The Canary Islands «ultraperipheral region» of the European Union. The case of agriculture. Revista de Derecho Comunitario Europeo, 14(36), 497-529.

Romero-Ternero, V., García-Rodríguez, L., \& Gómez-Camacho, C. (2005). Thermoeconomic analysis of wind powered seawater reverse osmosis desalination in the Canary Islands. Desalination, 186(1-3), 291-298. https://doi.org/ 10.1016/j.desal.2005.06.006

Ruiz-Romero, S., Colmenar-Santos, A., Gil-Ortego, R., \& Molina-Bonilla, A. (2013). Distributed generation: The definitive boost for renewable energy in Spain. Renewable Energy, 53, 354-364. https://doi.org/10.1016/j.renene. 2012.12.010

Sadhwani, J. Jaime; Veza, J. M. (2008). Desalination and energy consumption in Canary Islands. Desalination, 221, 143-150. https://doi.org/10.1016/j.desal.2007.02.051

Santamarta, J. C. (2014). Hidrología de las islas volcánicas; singularidades y contribución de la ingeniería forestal. Montes, 116, 26-31.

Santamarta, J. C., Lario-Bascones, R. J., Rodríguez-Martín, J., Hernández-Gutiérrez, L. E., \& Poncela, R. (2014). Introduction to Hydrology of Volcanic Islands. IERI Procedia, 9, 135-140. https://doi.org/10.1016/j.ieri.2014.09.053

Santamarta, J. (2011). El agua en Canarias: Historia, ciencia y tecnología. Boletín Anual Nautis et Incolis, $N^{\circ} 9$, 348-377.

Santamarta, J. C. (2013). Hidrología y recursos hídricos en islas y terrenos volcánicos. Colegio de Ingenieros de Montes.

Santamartal, J. C. (2016). Tratado de Minería de Recursos Hídricos en Islas Volcánicas Oceánicas Tratado de Minería. Colegio Oficial de Ingenieros de Minas del Sur de España.

Santana-Jiménez, Y., \& Hernández, J. M. (2011). Estimating the effect of overcrowding on tourist attraction: The case of Canary Islands. Tourism Management, 32(2), 415-425. https://doi.org/10.1016/j.tourman.2010.03.013 
Schallenberg-Rodríguez, Julieta; Veza, José Miguel; BlancoMarigorta, A. (2014). Energy efficiency and desalination in the Canary Islands. Renewable and Sustainables Energy Review, 40, 741-748. https://doi.org/10.1016/j. rser.2014.07.213

Arenas Urrea, sigrid; Díaz Reyes, Felipe; Peñate suárez, Baltasar; de la Fuente Bencomo, J. A. (2019). Technical review, evaluation and efficiency of energy recovery devices installed in the Canary Islands desalination plants. Desalination, 450, 54-63. https://doi.org/10.1016/j.desal. 2018.07.013
Veigas, M., \& Iglesias, G. (2013). Wave and offshore wind potential for the island of Tenerife. Energy Conversion and Management, 76, 738-745. https://doi.org/10.1016/j. enconman.2013.08.020

Publisher's note Springer Nature remains neutral with regard to jurisdictional claims in published maps and institutional affiliations. 